\title{
Safety evaluation and analgesic studies of defatted methanol extract of Capparis spinosa L. (Capparidaceae) fruits and roots bark in albino wistar rats
}

\author{
Asma Meddour, Mouloud Yahia, Leila Hambaba \\ Laboratory of Biotechnology of the Bioactive Molecules and Cellular Physiopathology, Department of Biology, \\ University of Batna 2, Algeria
}

\begin{abstract}
Capparis spinosa L. is an indigenous plant from Algeria but has widespread distribution in Mediterranean area. It is used by the local populations in traditional medicine for the treatment of various diseases. The purpose of this study is to test toxicity and analgesic effect of defatted methanol extract of fruits and roots bark of this plant in albino Wistar rats. To evaluate the acute toxicity, $500-5000 \mathrm{mg} / \mathrm{kg}$ body weight of each extract was administered orally to rats; symptoms of toxicity and mortality were observed for $72 \mathrm{~h}$. The results revealed the absence of toxicity for both extracts. In sub-chronic toxicity, rats were treated, with doses of 100 and $200 \mathrm{mg} / \mathrm{kg} /$ day of each extract, they were surveyed for four weeks, no symptoms of toxicity were observed. These results were confirmed by the blood biochemical analyses and the histopathology study of liver and kidney. Peripheral analgesic activity was tested orally at the dose of 100 and $200 \mathrm{mg} / \mathrm{kg}$ for each extract against pain induced by acetic acid. The dose of $200 \mathrm{mg} / \mathrm{kg}$ of both extracts presented significant analgesic effect, compared to the positive control; the acetylsalicylic acid.
\end{abstract}

Correspondence: Asma Meddour, Laboratory of Biotechnology of the Bioactive Molecules and Cellular Physiopathology, Department of Biology, University of Batna 2, Algeria.

Tel.: +213.0.698.731.400.

E-mail: bioasmed@yahoo.fr

Key words: Caper plant; Extract; Toxicity; Oral medium lethal dose $\left(\mathrm{LD}_{50}\right)$; Inhibition torsions percentage; Protective effect.

Contributions: the authors contributed equally.

Conflict of interest: the authors declare no potential conflict of interest.

Funding: none

Received for publication: 31 March 2018.

Revision received: 15 November 2018.

Accepted for publication: 19 November 2018.

(C) Copyright A. Meddour et al., 2019

Licensee PAGEPress, Italy

Journal of Biological Research 2019; 92:7456

doi:10.4081/jbr.2019.7456

This article is distributed under the terms of the Creative Commons Attribution Noncommercial License (by-nc 4.0) which permits any noncommercial use, distribution, and reproduction in any medium, provided the original author(s) and source are credited.

\section{Introduction}

Capparis spinosa L. or caper plant, also known as Kabbar or Thailalout is a long-lived shrubby plant which belongs to the genus of Capparis (family Capparidaceae) $)^{1,2}$ very widespread in the Mediterranean countries. ${ }^{3,4}$ In Algeria, it is grown as native shrub especially in Aurès area. The plant is one of the medicinal and aromatic plants with high pharmaceutical and ecological values. ${ }^{1}$ It is spontaneous, xerophyte, halophile ${ }^{1}$ and provides a required condiment: the caper, ${ }^{5}$ the plant is also used as fodder or ornamental plant. $^{2}$

The vegetative parts of $C$. spinosa were reported to have several biological activities such as antioxidant, ${ }^{6}$ antifungal, ${ }^{7}$ antihepatotoxic, ${ }^{8}$ anti-inflammatory, ${ }^{9}$ antiallergic and antihistaminic, ${ }^{10}$ chondroprotective, ${ }^{11}$ hypolipidemic ${ }^{12}$ and photoprotective ${ }^{13}$ activities.

The composition of $C$. spinosa have been widely evaluated, it consists of glycosides, flavonoïdes, alkaloids, terpenes, essential oils, fatty acids, steroids, glucosinolates, ${ }^{11,14-16}$ carotenoids and tocopherols. ${ }^{17}$ Vitamins such as vitamin $\mathrm{C},{ }^{16}$ proteins ${ }^{18}$ and biogenic salts like $\mathrm{K}, \mathrm{Mg}, \mathrm{Ca}, \mathrm{Na}, \mathrm{Zn}, \mathrm{Cu}, \mathrm{Fe}$ and P. ${ }^{19,20}$

Capparis spinosa have been widely studied ${ }^{1,6-13}$ but no work has been done concerning its toxicological profile. The present study aims at assessing the safety of degreased methanol extract of the fruits and roots bark of $C$. spinosa by acute and sub-chronic toxicity studies on liver and kidney functional indices in albino Wistar rats, and estimating the analgesic activity by writhing test.

\section{Materials and Methods}

\section{Plant material}

The fruits and roots of Capparis spinosa L. were collected from Batna region (northeastern Algeria), in October 2012. The plant was identified by Pr. OUDJHIH. Veterinary and Agronomic Sciences Institute, University of Batna 1. The plant parts: roots bark and the fruits, were, separately, air dried and crushed using laboratory mortar (Retsch).

\section{Sample preparation and extraction}

Powdered materials were extracted, separately, at a ratio of 1:6 (W/V) by maceration in sequential gradient solvents: petroleum ether, chloroform and methanol with intermittent shaking for 24 hours according to Ene et al. ${ }^{21}$ The mixtures were then filtered and the methanol extracts were concentrated at $45^{\circ} \mathrm{C}$ under reduced pressure using rotatory evaporator (Buchi Rotavapor) to obtain a roots bark defatted methanol extract $\left(\mathrm{E}_{\mathrm{r}} \mathrm{MeOH}\right)$ and fruits defatted methanol extract $\left(\mathrm{E}_{\mathrm{f}} \mathrm{MeOH}\right)$. 


\section{Animals}

Experiments were performed using albino Wistar healthy rats of either sex weighting $(140 \pm 20) \mathrm{g}$, obtained from the stock colony of Biotechnology of the Bioactive Molecules and Cellular Physiopathology Laboratory. Animals were allowed to free access to aliment and water ad libitum, they were fasted 18 hours before and three hours after the extract administration.

Experiments were conducted in accordance with the guideline 420 of the Organization for Economic Cooperation and Development. $^{22}$

\section{Phytochemical screening}

Both extracts were tested for the presence of alkaloids, tannins, carbohydrates, reducing sugar, phytosterols and phenolics by a standard phytochemical screening. ${ }^{23}$

\section{Acute toxicity study}

The oral medium lethal dose $\left(\mathrm{LD}_{50}\right)$ was determined according to Hamilton et $a l .{ }^{24}$ For each extract, 36 rats were arranged randomly into six groups (6 per group).

Increasing doses $(0,500,1000,1500,2000$ and $5000 \mathrm{mg} / \mathrm{Kg})$ were administered orally in a stepwise procedure (group by group) to rats. The treated rats were kept under observation during three days for any signs of toxicity or mortality.

The $\mathrm{LD}_{50}$ value of each extract was calculated arithmetically using the formula:

$$
\mathrm{LD}_{50}=\text { Least Lethal Dose }-\sum(\mathrm{a} \times \mathrm{b}) / \mathrm{n}
$$

Where: a: difference between two successive doses, b: mean mortality, n: number of animals in each group.

\section{Sub-chronic toxicity}

In this experience, five groups of six rats (three male and three female) were used, a control group (group 1) received distilled water. The second and the forth group received $100 \mathrm{mg} / \mathrm{kg}$ of the $\mathrm{E}_{\mathrm{f}} \mathrm{MeOH}$ and $\mathrm{E}_{\mathrm{r}} \mathrm{MeOH}$ respectively. Finally, the third and the fifth group received $200 \mathrm{mg} / \mathrm{kg}$ of the $\mathrm{E}_{\mathrm{f}} \mathrm{MeOH}$ and $\mathrm{E}_{\mathrm{r}} \mathrm{MeOH}$ respectively.

The treatments were given daily during 28 days, in which rats were supervised for all signs of toxicity or mortality. Their weight was measured weekly.

At the end of experience, blood samples were collected in heparin tubes for biochemical tests (glucose, cholesterol, triglycerides, total bilirubin, serum glutamate oxaloacetate transaminase (SGOT), serum glutamate pyruvate transaminase (SGPT), serum urea and creatinine) and the animals were sacrificed under ether anaesthesia.

Heart, liver, kidney and lungs of each rat were excised, observed, weighed and the organ/body weight was calculated. A portion of the liver and the kidney was fixed in formaldehyde $10 \%$ for histo-pathological studies.

\section{Analgesic activity}

In this experiment female rats of $150 \pm 10 \mathrm{~g}$ body weight were kept at the laboratory animal house under $12 \mathrm{~h} / 12 \mathrm{~h}$ light-dark cycle conditions and were allowed to free access of water and aliments according to the method cited by Siegmund et al..$^{25}$

\section{Animal allotment and treatment}

The animals were randomly distributed into six groups of six each: Group 1 served as a neutral control, received distilled water; Group 2 served as a positive control, received $100 \mathrm{mg} / \mathrm{kg}$ acetyl salicylic acid; ${ }^{26}$
Group 3 and group 4 received 100 and $200 \mathrm{mg} / \mathrm{kg}$ of $\mathrm{E}_{\mathrm{f}} \mathrm{MeOH}$ respectively;

Group 5 and group 6 received 100 and $200 \mathrm{mg} / \mathrm{kg}$ of $\mathrm{E}_{\mathrm{r}} \mathrm{MeOH}$ respectively.

\section{Writhing test}

One hour after administration of the treatments, $0.1 \mathrm{~mL} / 10 \mathrm{~g}$ of acetic acid solution $(0.6 \%) \mathrm{v} / \mathrm{v}$ was injected intraperitoneally to each animal. The number of writhing produced in these animals was counted for $20 \mathrm{~min}$, starting $5 \mathrm{~min}$ after acid injection. The percentage of the analgesic activity was calculated as follows:

$$
\text { Inhibition }(\%)=[(\mathrm{Nc}-\mathrm{Nt}) / \mathrm{Nc}] \times 100
$$

Where Nc: mean number of writhing in control group; Nt: mean number of writhing in treated group.

\section{Statistical analyses}

Results are presented as mean \pm SD of six repetitions. Statistical differences were analysed by the statistical software Graph Pad Prism 5 using one-way analysis of variance (ANOVA) followed by Tukey test.

\section{Results}

\section{Phytochemical screening}

The results of the phytochemical screening revealed the presence of all tested metabolites except tannins, these findings agreed with other previous studies. ${ }^{26-28}$

\section{Acute toxicity}

The present study did not produce any symptom of toxicity (restlessness, hematuria, diarrhea and muscle-coordinated movement) nor mortality during the three days with all the different doses used. No mortality was recorded throughout a week for both sexes. An abdominal muscle contraction in three rats during three hours after gavage with the dose $5000 \mathrm{mg} / \mathrm{kg}$ of $\mathrm{E}_{\mathrm{f}} \mathrm{MeOH}$ was observed. Thus, the $\mathrm{LD}_{50}$ is higher than $5000 \mathrm{mg} / \mathrm{kg}$.

\section{Sub-chronic toxicity}

In sub-chronic toxicity no signs of toxicity (loss of appetite, abdominal contraction, diarrhea, accelerated breathing and paralysis) were observed during the entire 28 days period of treatment.

At $\mathrm{P} \leq 0.05$ no significant differences in body weight gain was observed between the treated and the control (-) group for both extracts and with the different doses as it is indicated in Figure 1.

According to Figure 2, same results were observed for organ body weight. At $\mathrm{P} \leq 0.05$ no significant differences was recorded between the treated and the control groups.

Data on various blood parameters such as glucose, cholesterol, triglycerides, total bilirubin, SGOT, SGPT, serum urea and creatinine are represented in Table 1.

According to Table 1, glucose, triglycerides, urea and creatinine levels were not significantly affected when compared with control group. In contrary cholesterol level increased in treated animals in a dose dependent manner, whereas the levels of the liver transaminases were decreased especially in treated animals with the dose of $200 \mathrm{mg} / \mathrm{kg}$ of $\mathrm{E}_{\mathrm{f}} \mathrm{MeOH}$.

No morphologic abnormalities were observed in heart, lungs, 
liver and kidney. The naked eye and the microscopic examination of liver and kidney did not show any histo-pathological alterations; in liver, they were characterized by normal hepatic cells; with distinct nuclei and normal eosinophilic cytoplasm with normal sinusoids. The kidney showed a preservation of the cellular renal architecture with normal glomerules, proximal tubules and collecting ducts. The adrenal glands showed normal layer of cells in both cortex and medulla of animals treated (Figures 3 and 4).

\section{Analgesic activity}

The oral administration of defatted methanol extract of fruits and root barks of Capparis spinosa in rats significantly reduced, in a dose-dependent manner, the number of abdominal constrictions induced by acetic acid as compared to control group. A protective effect of $81.68 \%$ and $88.51 \%$ were observed in the treated groups by $\mathrm{E}_{\mathrm{r}} \mathrm{MeOH}$ at doses of $100 \mathrm{mg} / \mathrm{kg}$ and $200 \mathrm{mg} / \mathrm{kg}$ respectively. However, $\mathrm{E}_{\mathrm{f}} \mathrm{MeOH}$ showed $80.43 \%$ and $67.08 \%$ of protective effect, at doses of 200 and 100 respectively. The inhibition produced by the dose $200 \mathrm{mg} / \mathrm{kg}$ of $\mathrm{E}_{\mathrm{r}} \mathrm{MeOH}$ was not significantly $(\mathrm{P} \leq 0.001)$ different than that observed with acetylsalicylic acid $(100 \mathrm{mg} / \mathrm{kg})$ which showed a protective effect of $92.55 \%$ (Figure 5).

\section{Discussion}

In the literature, there are very few reports on the safety of Capparis spinosa, compared to the research on its biological activities, despite it is an ancient herb that has been widely used as condiment and drogue in traditional and alternative medicine.

Our results are in agreement with those found by Karanayil et al.,${ }^{29}$ who reported an $\mathrm{LD}_{50}$ superior to $5000 \mathrm{mg} / \mathrm{kg}$ for C. spinosa. However, this dose may cause allergic contact dermatitis with inflamed skin in prolonged use. ${ }^{30,31}$

Liver and kidney were chosen for the histo-pathological study because they play an essential role in the organism, detoxifying the xenobiotics, drugs and toxic molecules. The liver plays a principal role in transforming these molecules leading to the toxicity from these agents. ${ }^{32-36}$

Table 1. Effect of two doses of $\mathrm{E}_{\mathrm{f}} \mathrm{MeOH}$ and $\mathrm{E}_{\mathrm{r}} \mathrm{MeOH}$ on blood biochemical parameters of rats.

\begin{tabular}{|c|c|c|c|c|c|}
\hline Parameters & Control (-) & $\mathrm{E}_{\mathrm{f}} \mathrm{MeOH} 100 \mathrm{mg} / \mathrm{kg}$ & E $\mathrm{MeOH} 200 \mathrm{mg} / \mathrm{kg}$ & E.MeOH 100mg/kg & E.MeOH $200 \mathrm{mg} / \mathrm{kg}$ \\
\hline Glucose (g/L) & $0.924 \pm 0.058$ & $0.900 \pm 0.164^{\mathrm{a}}$ & $0.910 \pm 0.044^{\mathrm{a}}$ & $0.985 \pm 0.016^{\mathrm{a}}$ & $0.985 \pm 0.016^{\mathrm{a}}$ \\
\hline Cholesterol (g/L) & $0.478 \pm 0.072$ & $0.510 \pm 0.033^{a}$ & $0.635 \pm 0.060$ & $0.590 \pm 0.066$ & $0.610 \pm 0.044$ \\
\hline Triglycerides (g/L) & $1.178 \pm 0.271$ & $1.020 \pm 0.285^{\mathrm{a}}$ & $0.880 \pm 0.296^{\mathrm{a}}$ & $0.955 \pm 0.170^{a}$ & $1.060 \pm 0.285^{\mathrm{a}}$ \\
\hline SGOT (U/L) & $132.792 \pm 15.171$ & $112.500 \pm 1.643$ & $094.000 \pm 3.286$ & $116.000 \pm 16.432$ & $139.000 \pm 8.764^{\mathrm{a}}$ \\
\hline SGPT (U/L) & $87.760 \pm 9.040$ & $96.000 \pm 3.286^{\mathrm{a}}$ & $59.167 \pm 1.941$ & $78.500 \pm 2.739^{a}$ & $84.000 \pm 8.764^{\mathrm{a}}$ \\
\hline Urea (g/L) & $0.344 \pm 0.031$ & $0.340 \pm 0.021^{\mathrm{a}}$ & $0.390 \pm 0.066^{a}$ & $0.350 \pm 0.033^{a}$ & $0.385 \pm 0.005^{\mathrm{a}}$ \\
\hline Creatinine (mg/L) & $5.000 \pm 0.000$ & $5.000 \pm 0.000^{\mathrm{a}}$ & $5.000 \pm 0.000^{\mathrm{a}}$ & $5.000 \pm 0.000^{a}$ & $5.000 \pm 0.000^{\mathrm{a}}$ \\
\hline
\end{tabular}

Values are mean \pm SD of six animals. atest values carrying superscripts different at $<0.05$ compared to control group.; SGOT, serum glutamate oxaloacetate transaminase; SGPT, serum glutamate pyruvate transaminase.

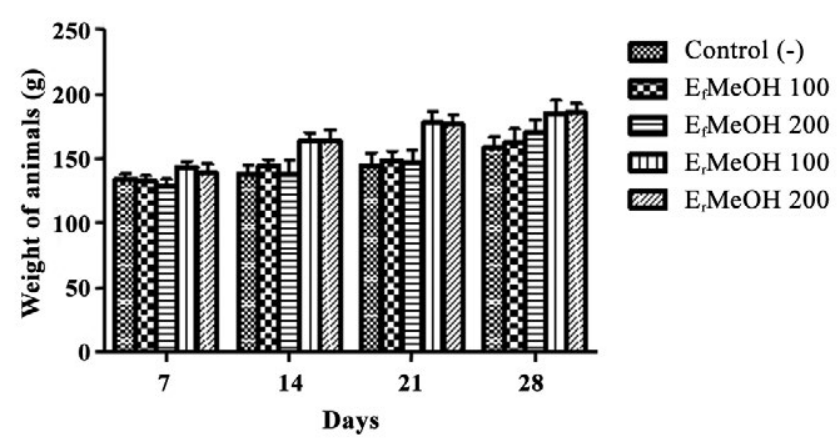

Figure 1. Evolution of the body weight of animals during the experimental period. Values are mean $\pm S D$ of six animals.

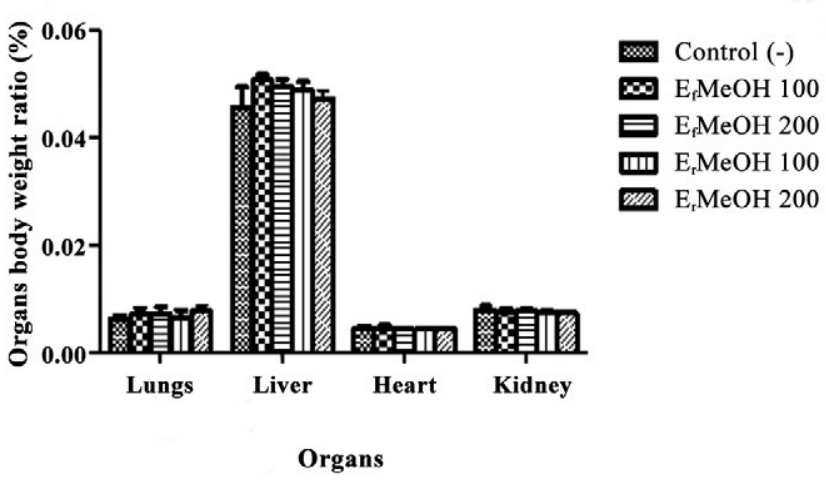

Figure 2. Effect of different doses of $\mathrm{E}_{\mathrm{f}} \mathrm{MeOH}$ and $\mathrm{E}_{\mathrm{r}} \mathrm{MeOH}$ on organs body weight ratio of the experiment rats. Values are mean $\pm S D$ of six animals. 
Several research evaluating the safety of the genus Capparis; the effect of C. erythrocarpus on chronic administration using histopathological studies was published, ${ }^{32}$ according to their results, the morphology of the liver, kidney and heart tissues was not affected. Same results were found for $C$. sepiaria ethanolic extract ${ }^{33}$ and $C$. grandiflora ${ }^{34}$ which did not show any acute, sub-acute or chronic toxicity. Otherwise, $C$. tomentosa has been reported to be toxic. A depression in central nervous system was observed with aerial parts of $C$. moonii ethanolic extracts. ${ }^{31}$

The biochemical parameters of cholesterol and liver transaminases showed a significant difference $(\mathrm{P}<0.05)$. However, according to Sharp and La Regina, ${ }^{35}$ the ranges of clinical chemistry for rats are large (52-224 IU/1 range interval of SGPT for example).

These results were concluded the safety of this plant and justify its traditional use by peoples. Despite the importance of these results, clinical tests are necessary.

Acetic acid writhing test is used to evaluate the compounds for peripheral antinociceptive activities. ${ }^{37}$ It is useful to discriminate central and peripheral nociception. ${ }^{37}$ The cramps appeared following the injection of the acetic acid are produced by peripheral mediators such as prostaglandins. It is suggested that the extract expressed this antalgic capacity by the inhibition of the synthesis of these mediators.
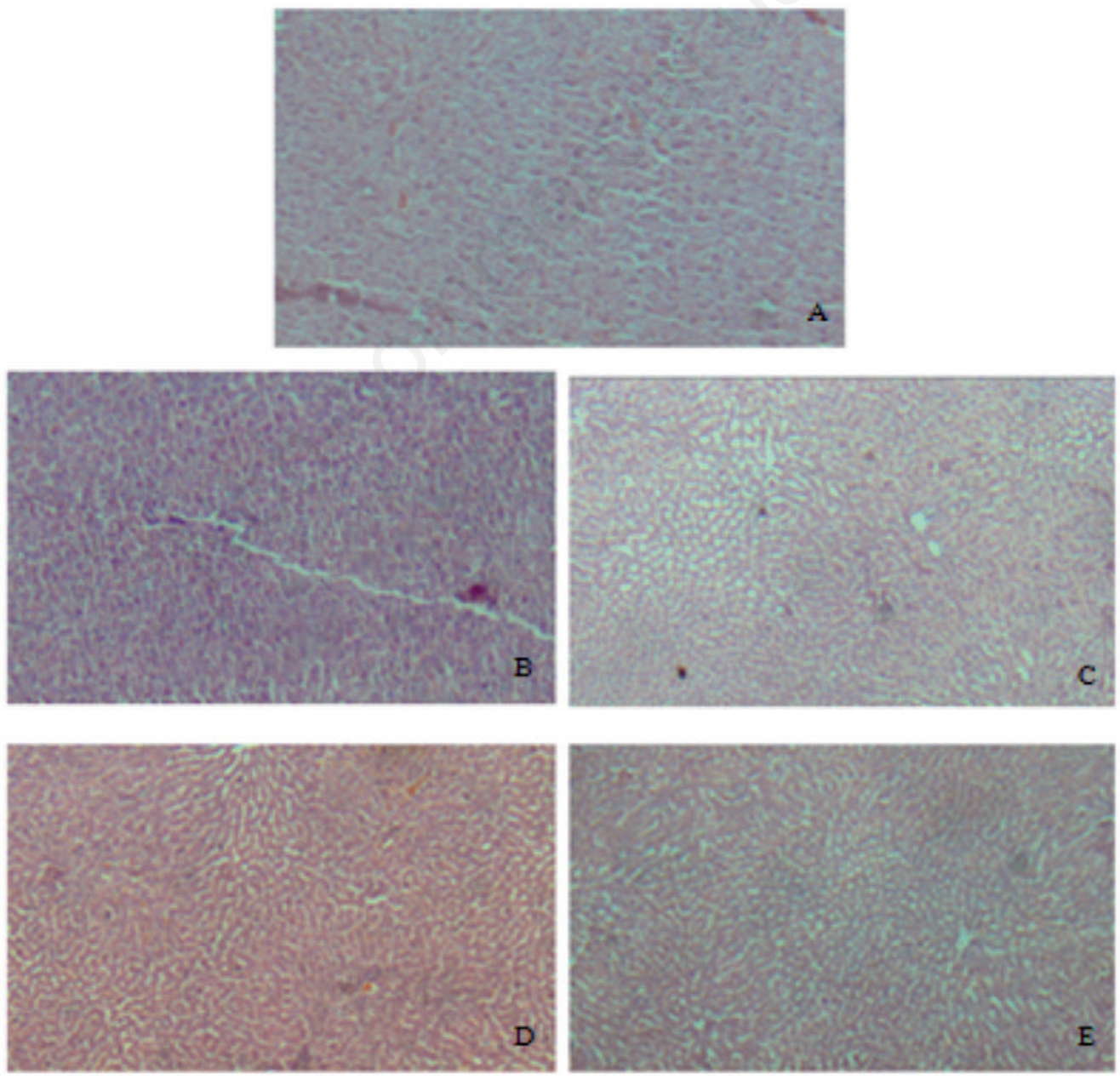

Figure 3. Histopathological sections of liver of rats on sub-chronic toxicity; in order: (A) control group rats; $(\mathrm{B}, \mathrm{C})$ rats treated with 100 $\mathrm{mg} / \mathrm{kg}$ and $200 \mathrm{mg} / \mathrm{kg}$ of $\mathrm{E}_{\mathrm{f}} \mathrm{MeOH} ;(\mathrm{D}, \mathrm{E})$ rats treated with $100 \mathrm{mg} / \mathrm{kg}$ and $200 \mathrm{mg} / \mathrm{kg}$ of $\mathrm{E}_{\mathrm{r}} \mathrm{MeOH}$. 
Results of analgesic activity showed that the extracts tested, have a significant dose-dependent analgesic effects. In fact, a dose of 200 $\mathrm{mg} / \mathrm{kg}$ has a similar action to that of acetylsalicylic acid $(100 \mathrm{mg} / \mathrm{kg})$. Preliminary phytochemical experiments indicated the presence of alkaloids and phenolics, which may be responsible for the analgesic activity. This can be checked only by the realization of better-targeted pharmacological tests to elucidate the exact mechanism of action.

Related studies in Capparidaceae family have demonstrated that different species exhibit an analgesic activity such as: Capparis zeylanica $^{26}$ and Capparis ovate. ${ }^{38}$ These results agree with her traditional use especially against the dental pain and rheumatisms (the broadest uses in the area where made harvest).

\section{Conclusions}

In conclusion, the results of the present study clearly showed that the $\mathrm{E}_{\mathrm{r}} \mathrm{MeOH}$ and $\mathrm{E}_{\mathrm{f}} \mathrm{MeOH}$ under the conditions tested, did not induce acute or sub-chronic toxic effects in albino Wistar rats, and indicate that the extract possess analgesic properties.

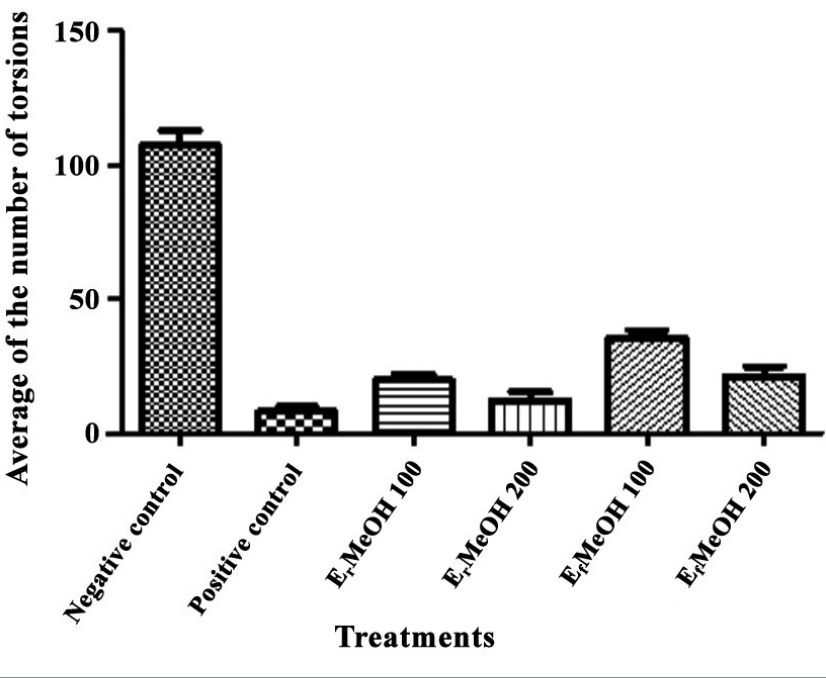

Figure 5. Effects of $\mathrm{E}_{\mathrm{f}} \mathrm{MeOH}$ and $\mathrm{E}_{\mathrm{r}} \mathrm{MeOH}$ of Capparis spinosa on acetic acid-induced pain in rats. Each bar represents the mean \pm SD of 6 animals.
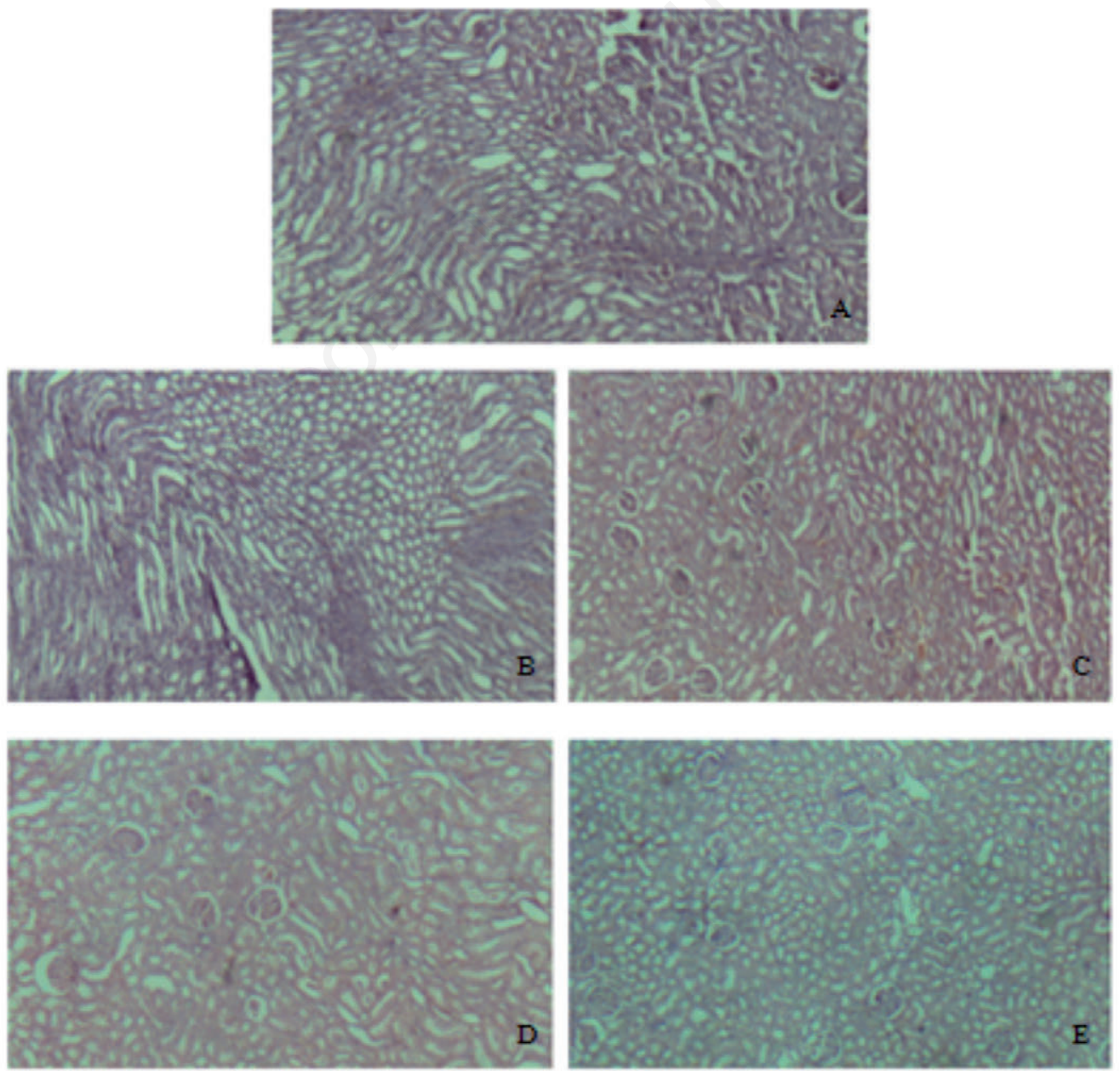

Figure 4. Histopathological sections of kidney of rats on sub-chronic toxicity; in order: (A) control group rats; (B, C) rats treated with $100 \mathrm{mg} / \mathrm{kg}$ and $200 \mathrm{mg} / \mathrm{kg}$ of $\mathrm{E}_{\mathrm{f}} \mathrm{MeOH}$; (D, E) rats treated with $100 \mathrm{mg} / \mathrm{kg}$ and $200 \mathrm{mg} / \mathrm{kg} \mathrm{of} \mathrm{E}_{\mathrm{r}} \mathrm{MeOH}$. 


\section{References}

1. Benseghir-Boukhari LA, Seridi R. Le câprier, une espèce arbustive pour le développement rural durable en Algérie. Méditerranée 2007;109:100-5.

2. Quezel P, Santa S. Nouvelle flore de l'Algérie et régions désertiques méridionales. Paris, FR: National Center of Research; 1962.

3. Aghel N, Rashidi I, Mombeini A. Hepatoprotective Activity of Capparis spinosa Root Bark Against CCl4 Induced Hepatic Damage in Mice. Iran J Pharm Res 2007;6:285-90.

4. Romeo V, Ziino M, Giuffrida D, et al. Flavour profile of capers (Capparis spinosa L) from the Eolian Archipelago by HSSPME/GC-MS. Food Chem 2007;101:1272-8.

5. Douieb H, Benlemlih M. Improvement organoleptic qualities of fermented caper through an experimental factorial design Capparis spinosa L. Internet J Food Safety 2010;12:35-44.

6. Germano MP, De Pasquale R, D'Angelo V, et al. Evalution of extracts and isolated fraction from Capparis spinosa L. buds as antioxidant source. J Agric Food Chem 2002;50:1168-71.

7. Ali-Shtayeh MS, Abu-Ghdeib SI. Antifungal activity of plant extracts against dermatophytes. Mycoses 1999;42:665-72.

8. Gadgoli C, Mishra SH. Antihepatotoxic activity of pmethoxybenzoic acid from Capparis spinosa. J Ethnopharmacol 1999;66:187-92.

9. Al-Said MS, Abdelsattar EA, Khalifa SI, El-Feraly FS. Isolation and identification of an anti-inflammatory principle from Capparis spinosa. Pharmazie 1988;43:640-1.

10. Trombetta D, Occhiuto F, Perri D, et al. Antiallergic and antihistaminic effect of two extracts of Capparis spinosa L. flowering buds. Phytother Res 2005;19:29-33.

11. Panico AM, Cardile V, Garufi F, et al. Protective effect of Capparis spinosa on chondrocytes. Life Sci 2005:77;2479-88.

12. Eddouks M, Lemhadri A, Michel JB. Hypolipidemic activity of aqueous extract of Capparis spinosa L. in normal and diabetic rats. J Ethnopharmacol 2005;98:345-50.

13. Bonina F, Puglia $C$, Ventura $D$, et al. In vitro antioxidant and in vivo photoprotective effects of a lyophilized extract of Capparis spinosa L. buds. J Cosmet Sci 2002;53:321-35.

14. Matthous B, Ozcan M. Glucosinolates and fatty acid, sterol, and tocopherol composition of seed oils from Capparis spinosa Var. spinosa and Capparis ovata Desf. Var. canescens (Coss.) Heywood. J Agric Food Chem 2005;53:7136-41.

15. Liu YQ, Wang CH, Wang ZT. Advances on investigation of chemical constituents, pharmacological activities and clinical applications of Capparis spinosa. Zhongguo Zhong Yao Za Zhi 2008:33;2453-8.

16. Tesoriere L, Butera D, Gentile, Livrea MA. Bioactive components of caper (Capparis spinosa L.) from Sicily and antioxidant effects in a red meat simulated gastric digestion. J Agric Food Chem 2007:55;8465-71.

17. Tlili N, Nasri N, Saadaori E, et al. Carotenoid and tocopherol composition of leaves, buds, and flowers of Capparis spinosa grown wild in Tunisia. J Agric Food Chem 2009;57:5381-5.

18. Demir Y, Güngor AA, Duran ED, Demir N. Cysteine Protease (Capparin) from Capsules of Caper (Capparis spinosa). Food Technol Biotechnol 2008;46:286-91.

19. Rodrigo M, Lazaro MJ, Alvarruiz A, Giner V. Composition of
Capers (Capparis spinosa): Influence of Cultivar, Size and Harvest Date. J Food Sci 2006;57:1152-4.

20. Giuffrida D, Salvo F, Ziino M, Toscano G. Initial investigation on some chemical constituents of capers (Capparis spinosa L.) from the Island of Salina. Ital J Food Sci 2002;1:25-33.

21. Ene AC, Atawodi SE, Ameh DA, et al. Antitrypanosomal effects of petroleum, chloroform and methanol extracts of Artemisia maciverae Linn. Indian J Exp Biol 2009;47:981-6.

22. OECD 420. Guideline for testing of chemicals: Acute oral toxicité - Fixed dose procedure; 2001. Available from: https://ntp. niehs.nih.gov/iccvam/suppdocs/.../oecd/oecd_gl420.pdf

23. Tiwari P, Kumar B, Kaur M, et al. Phytochemical screening and extraction: A review. Int Pharm Sci 2011;1:98-106.

24. Hamilton MA, Russo RC, Thurston RV. Trimed SpearmanKarber method for estimating median lethal concentrations in toxicity bioassays. Environ Sci Technol 1977;7:714-9.

25. Siegmund E, Cadmus R, Lu G. A method for evaluating both non-narcotic and narcotic analgesics. Pro Soc Exp Biol Med 1957;95:729-31.

26. Ghule BV, Murugananthan G, Yeole PG. Analgesic and antipyretic effects of Capparis zeylanica leaves. Fitoterapia 2007;78:365-9.

27. Matthous B, Ozcan M. Glucosinolates and fatty acid, sterol, and tocopherol composition of seed oils from Capparis spinosa Var. spinosa and Capparis ovata Desf. Var. canescens (Coss) Heywood. J Agric Food Chem 2005;53:7136-41.

28. Liu YQ, Wang CH, Wang ZT. Advances on investigation of chemical constituents, pharmacological activities and clinical applications of Capparis spinosa. China J Chin Mat Med 2008;33:2453-8.

29. Karanayil RS, Barij NS, Aiyolu R. Protective Effects of Capparis zeylanica Linn. Leaf Extract on Gastric Lesions in Experimental Animals. Avicenna J Med Biotech 2011;3:31-5.

30. Angelini G, Vena GA, Filotico R, et al. Allergic contact dermatitis from Capparis spinosa L. applied as wet compresses. Contact Dermat 1991;24:382-3.

31. Mishra SN, Tomar PC, Lakra N. Medicinal and food value of Capparis - a harsh terrain plant. J Trad Knowledge 2007;6:230-8.

32. Martey ON, Armah GE, Sittie AA, Okine LK. A chronic toxicity study of the ground root bark of Capparis erythrocarpus (Cappareceae) in male Sprague-Dawley rats. Pak J Biol Sci 2013;16:1706-13.

33. Rajesh P, Latha S, Selvamani P, Rajesh Kannan V. Phytochemical Screening and Toxicity Studies on the Leaves of Capparis sepiaria Linn. (Capparidaceae). J Basic Clin Pharm 2010;1:41-6.

34. Sini KR, Sinha BN, Rajasekaran A. Acute toxicity studies of aqueous leaf extract of Capparis grandiflora. J Chem Pharm Res 2010;2:112-7.

35. Sharp PE, La Regina MC. The laboratory rat. USA: CRC Press LLC; 1998.

36. Pal RK, Manoj J. Hepatoprotective activity of alcoholic and aqueous extracts of fruits of Luffa cylindrica Linn in rats. Ann Biol Res 2011;2:132-41.

37. Le Bars D, Gozariu M, Cadden S. Animal models of nociception. Pharmacol Rev 2001;53:628-51.

38. Arslan R, Bektas N, Ozturk Y. Antinociceptive activity of methanol extract of fruits of Capparis ovata in mice. J Ethnopharmacol 2010;131:28-32. 